To cite: JP Perez-Leon-Acevedo 'Stopping mass atrocities in Africa and the Pretoria Principles: Triggering military intervention in Darfur (Sudan) and Libya under article 4(h) of the Constitutive Act of the African Union' (2016) 16

\title{
Stopping mass atrocities in Africa and the Pretoria Principles: Triggering military intervention in Darfur (Sudan) and Libya under article 4(h) of the Constitutive Act of the African Union
}

\section{Juan-Pablo Perez-Leon-Acevedo*}

Post-doctoral Fellow, PluriCourts, Faculty of Law, University of Oslo, Norway; former Vice-Chancellor's Post-Doctoral Fellow, Centre for Human Rights, Faculty of Law, University of Pretoria, South Africa

\section{Summary}

This article examines article 4(h) of the Constitutive Act of the African Union, which provides for military intervention in an AU member state by the $A U$ to stop mass atrocities, namely, serious human rights violations constitutive of international crimes. The article identifies a five-prong, sequential and cumulative test as applied in Darfur (Sudan) and Libya. This test is largely based on article 4(h), the Pretoria Principles on Ending Mass Atrocities Pursuant to Article 4(h) of the Constitutive Act of the African Union, and related sources. Although not binding, the Pretoria Principles, drafted and adopted by a group of experts following a conference convened by the University of Pretoria in December 2012, provide a complete set of guidelines to apply and implement article 4(h). In applying this test, it is concluded that article 4(h) should have been applied and is still applicable in Darfur and Libya.

Key words: article 4(h) of the Constitutive Act of the African Union; African Union; Pretoria Principles; mass atrocities; responsibility to protect; Security Council; Darfur (Sudan); Libya; International Criminal Court

LLB (Catholic University of Peru) LLM (Columbia, USA) PhD (Åbo Akademi, Finland); juanpp@jus.uio.no This article was largely prepared during the time the author spent as Vice-Chancellor's Post-Doctoral Fellow, Centre for Human Rights, Faculty of Law, University of Pretoria. 


\section{Introduction}

According to article 4(h) of the Constitutive Act of the African Union $(\mathrm{AU}){ }^{1}$ an $\mathrm{AU}$ principle is 'the right of the Union to intervene in a member state pursuant to a decision of the Assembly in respect of grave circumstances, namely: war crimes, genocide and crimes against humanity'. Article 4(j) of the Protocol Relating to the Establishment of the Peace and Security Council (PSC) of the $\mathrm{AU}^{2}$ restates this principle.

Based on article 4(h), the Pretoria Principles ${ }^{3}$ and related literature, ${ }^{4}$ the article seeks to, first, identify a test to trigger article 4(h) forceful intervention, namely, military intervention by the $A U$ in Darfur (Sudan) and Libya; second, to demonstrate that article 4(h) military intervention should have been applied and should still be applied in order to stop ongoing and prevent further mass atrocities in Darfur and Libya. Darfur and Libya are considered because of factors such as complexity, duration, international effects and gravity. As evidenced by sources discussed here, not only did Darfur and Libya constitute paradigmatic cases for military intervention in Africa but, additionally, the current situation on the ground arguably still merits military intervention. It may be argued that the current situation in Burundi warrants a more immediate triggering of article 4(h). However, considering the above-mentioned factors, Darfur and Libya deserve at least equal attention. The analysis is limited to these two cases in order to examine them in greater detail.

Data on mass atrocities in Darfur and Libya used here mainly stems from mechanisms at the international level, namely, the United Nations (UN) and the International Criminal Court (ICC), and is complemented by information from the AU mechanisms. The analysis focuses on the conditions under which to apply article 4(h) in Darfur and Libya. Considering the above-mentioned aims of the study, the implementation of article 4(h) is not, as such, discussed extensively. However, certain aspects relating to the implementation (and 'implementability') of article 4(h) are examined under the proposed test, particularly paying attention to the PSC structures, the role of the $\mathrm{AU}$ human rights system, and the $\mathrm{AU}$ Assembly in the matrix of implementation of article $4(\mathrm{~h})$.

The analysis presented builds on existing literature on article 4(h) and, to some extent, the responsibility to protect. Thus, the focus is on the application of doctrinal and legal considerations to the cases of

1 Constitutive Act of the African Union, adopted 11 July 2000, entered into force 26 May 2001.

2 Protocol Relating to the Establishment of the Peace and Security Council, adopted 9 July 2002, entered into force 26 December 2003.

3 Pretoria Principles on Ending Mass Atrocities Pursuant to Article 4(h) of the Constitutive Act of the African Union, Centre for Human Rights, Pretoria, 2012.

4 Eg, D Kuwali \& F Viljoen (eds) Africa and the responsibility to protect: Article 4(h) of the African Union Constitutive Act (2014). 
Darfur and Libya. Some theoretical consideration of article 4(h) is examined, as complemented by a discussion of the legal nature of the Pretoria Principles. Thereafter the study follows a proposed test to trigger military intervention by the $\mathrm{AU}$ in an $\mathrm{AU}$ member state in order to stop mass atrocities. This test consists of five sequential and cumulative criteria. First, there must be grave circumstances to be prevented or halted, namely, war crimes, genocide and crimes against humanity. Second, the target state must be unwilling or unable to stop these mass atrocities. Third, article 4(h), namely, military intervention, must be the last available resource or measure. Fourth, the AU Assembly should take the decision to intervene. Fifth, the AU must seek the authorisation of the UN Security Council.

\section{On the theoretical foundations of article 4(h) and the nature of the Pretoria Principles}

Regarding the theoretical foundations of article 4(h) for the purposes of this study, first, the responsibility to protect and its relationship to article 4(h) are examined. The responsibility to protect is not a binding legal principle capable of founding a case for military intervention by itself. This responsibility is fundamentally a political commitment carrying persuasive value. The lack of binding effect is caused mainly by the absence of consensus among states regarding the scope, manifestations and implementation of the responsibility to protect. $^{5}$ The three documents associated with its genesis, namely, the Report of the International Commission on State Sovereignty and Intervention (ICISS Report), ${ }^{6}$ the High-Level Panel Report (HIPPO Report), ${ }^{7}$ and the Outcome Document of the 2005 World Summit (Outcome Document), ${ }^{8}$ as well as the reports by the SecretaryGeneral on implementing the responsibility to protect, ${ }^{9}$ have not led to an emerging hard norm of international law. ${ }^{10}$ Rather, the responsibility to protect constitutes soft law or a political principle. ${ }^{11}$ The responsibility to protect is 'partly a political catchword', but some propositions on the responsibility are based on established

5 See C Focarelli 'The responsibility to protect doctrine and humanitarian intervention: Too many ambiguities for a working doctrine' (2008) 13 Journal of Conflict and Security Law 191-213.

6 ICISS 'The responsibility to protect' (2001) http://responsibilitytoprotect.org/ ICISS\%20Report.pdf (accessed 1 November 2016).

7 A more secure world: Our shared responsibility. Report of the High-Level Panel on Threats, Challenges and Change, UNGA Doc A/59/565, 2 December 2004.

8 The use of force in international relations: Challenges to collective security (2006) UN General Assembly, World Summit Outcome, 60th session, UN Doc A/60/L.1/2005, 15 September 2005.

9 Eg Report of the Secretary-General Implementing the responsibility to protect, A/63/ 677, 12 January 2009 paras 17-19 \& 53-54.

10 C Stahn 'Responsibility to protect: Political theory or emerging legal norm' (2007) 101 American Journal of International Law 99118.

11 As above. 
international law. ${ }^{12}$ The responsibility to protect is based on three pillars: states are primarily responsible for protecting their populations from mass atrocities; the international community has a duty to assist states to meet this responsibility; and if a state fails to protect its population, the international community should be prepared to take collective action (in principle via the UN Security Council) under the UN Charter. ${ }^{13}$ Article 4(h) corresponds to or is akin to this third pillar $^{14}$ and, arguably, codifies it to an important extent. ${ }^{15}$ As examined later, the kind of intervention under article 4(h) is primarily of a military nature or by the use of force. ${ }^{16}$ In this study the responsibility to protect is used as a general framework for article 4(h) which binds state parties to the AU Constitutive Act. Therefore, the responsibility to protect may be used as a persuasive ground for suggesting military intervention in situations that meet the article 4(h) threshold.

Second despite pursuing the same goal of the prevention of mass atrocities, ${ }^{17}$ article $4(\mathrm{~h})$ is different from humanitarian intervention. ${ }^{18}$ Unlike unilateral intervention (such as Tanzania's intervention in Uganda (1978)) or multilateral humanitarian intervention (North Atlantic Treaty Organisation (NATO)), article 4(h) intervention is a statutory treaty-based intervention, that is, based on a legal entitlement to intervene. ${ }^{19}$

Third, the approach of sovereignty as responsibility and the possibility to curtail sovereignty in cases of mass atrocities underlie article 4(h). Indeed, the rationale behind article 4(h) is to avoid genocidal massacres such as occurred in Rwanda (1994). AU member states are expected to prove that they fulfil their responsibility to protect their own populations so that no article $4(\mathrm{~h})$ intervention takes place. ${ }^{20}$

Regarding the nature of the Pretoria Principles, they neither constitute formal sources of international law nor generate international obligations. The Principles have no legal effect. However, they can add important persuasive value to invoke article $4(\mathrm{~h})$ in Darfur and Libya. Indeed, the Pretoria Principles may be placed within the context of similar initiatives, including the academic and non-

\footnotetext{
12 Stahn (n 10 above) 102.

13 UN General Assembly (n 8 above) paras 138-140.

14 D Kuwali 'Meaning of "intervention" under article 4(h)' in Kuwali \& Viljoen (n 4 above) 26; Pretoria Principle 5.

15 Pretoria Principle 5.

16 Kuwali (n 14 above) 26; A Abass 'The African Union and the responsibility to protect. Principles and limitations' in J Hoffmann \& A Nollkaemper (eds) Responsibility to protect: From principle to practice (2012) 213 224-226.

17 Abass (n 16 above) 223.

18 D Kuwali \& F Viljoen 'Conclusion' in Kuwali \& Viljoen (n 4 above) 341.

19 Kuwali (n 14 above) 32-33.

20 Stahn (n 10 above) 119; Kuwali (n 14 above) 31.
} 
academic sources examined in this study, on the importance of implementing article 4(h).

Whether the Pretoria Principles could be considered part of 'the teachings of the most highly-qualified publicists of the various nations, as subsidiary means for the determination of rules of law' under article $38(1)(d)$ of the Statute of the International Court of Justice, is open to debate. It may be argued that the Pretoria Principles represent the opinions of only a handful of scholars. Nevertheless, the Principles indeed resulted from a conference that brought together a significant number of scholars and experts on article 4(h), including several prominent legal scholars. A collective book on article $4(\mathrm{~h})$ related to the Pretoria Principles conference has been published, and civil society has made reference to the Principles. ${ }^{21}$ The Pretoria Principles and their 'companion' book arguably reflect 'the teachings of the most highly-qualified publicists of the various nations' in Africa on article 4(h).

It may be also argued that the Pretoria Principles constitute soft law. Although not constituting law, the Principles are legally relevant as they claim to seek to 'provide greater clarity and inform action' by a variety of regional, sub-regional, state and non-state actors on how to enhance their roles concerning article 4(h). ${ }^{22}$ Soft law consists of a wide variety of instruments, including statements prepared by individuals in a non-governmental capacity that seek to establish international principles. ${ }^{23}$ The Pretoria Principles fall in this soft law category. The Principles also serve certain roles that non-binding normative instruments can play in relation to hard law: consolidating political opinion around the need for action on a problem; filling in gaps in treaties; and providing guidance. ${ }^{24}$ Moreover, as the Principles may arguably carry political and/or moral value in international law, they may be considered soft law. ${ }^{25}$

\section{Existence of grave circumstances, namely, war crimes, genocide and crimes against humanity, to be prevented or halted}

Article 4(h) mentions intervention 'in respect of grave circumstances, namely, war crimes, genocide and crimes against humanity' - also

21 See Kuwali \& Viljoen (n 18 above); Stanley Foundation et al Civil society perspectives: A view from Africa: From non-interference to non-indifference: Reflecting on the implementation of the article 4(h) agenda at the African Union (2014).

22 Pretoria Principles introduction.

23 CM Chinkin 'The challenge of soft law: Development and change in international law' (1989) 38 International and Comparative Law Quarterly 850-851.

24 D Shelton 'Soft law' in D Armstrong (ed) Handbook of international law (2009) 68 72.

$25 \mathrm{M}$ Bothe 'Legal and non-legal norms: A meaningful distinction in international relations' (1980) 11 Netherlands Yearbook of International Law 67-95. 
mentioned in article 4(j) of the PSC Protocol. The Pretoria Principles provide:

8 The threshold for intervention pursuant to article 4(h) is 'grave circumstances' that constitute serious violations of human rights and humanitarian law in the form of genocide, war crimes and crimes against humanity.

9 Article 4(h) empowers the $\mathrm{AU}$ to intervene in a member state under a limited set of stipulated 'grave circumstances' ... when populations are at risk of war crimes, genocide and crimes against humanity.

This study examines article 4(h) as it currently stands: 'intervention in the event of grave circumstances (intervention to protect populations from mass atrocities) ${ }^{26}$ The instruments of the International Criminal Tribunals for the Former Yugoslavia and Rwanda (ICTY and ICTR), the ICC and Special Court for Sierra Leone include definitions of the above-mentioned crimes. These crimes have been interpreted in the robust case law of these tribunals. The commission of these crimes breaches ius cogens rules. ${ }^{27}$ For the purposes of this study, the ICC Statute provisions, which largely codify customary international law and bind most African states, suffice. Following the UN Genocide Convention, the ICC Statute in article 6 establishes that genocide consists of five criminal acts 'committed with intent to destroy, in whole or in part, a national, ethnical, racial or religious group'. Crimes against humanity (article 7 of the ICC Statute) refer to criminal acts such as murder, torture, sexual crimes and persecution 'committed as part of a widespread or systematic attack directed against any civilian population, with knowledge of the attack'. Finally, war crimes (article 8 of the ICC Statute) consist of serious violations of international humanitarian law committed in international or non-international armed conflicts.

A wide range of sources have extensively documented the commission of war crimes, genocide and/or crimes against humanity in Darfur and Libya. In this section some of these sources are discussed to evidence the protracted and continuous commission of mass atrocities and, thus, argue that 'grave circumstances', as laid down in article 4(h), not only existed but also continue to exist in Darfur and Libya. Regarding the findings, conclusions and recommendations of fact-finding commissions relating to crimes committed in Darfur and Libya, these arguably constitute soft law sources and should be considered by organs such as the UN Security Council, the AU Assembly and the PSC.

With respect to Darfur, under UN Security Council Resolution 1564 (2004), ${ }^{28}$ the Secretary-General established the International Commission of Inquiry on Darfur (ICID). In 2005 the ICID concluded

26 Pretoria Principle 2.

27 W Schabas An introduction to the International Criminal Court (2004) 34.

28 S/RES/1564 (2014), 18 September 2014 para 12. 
that Sudan and the state-affiliated Janjaweed were responsible for serious violations of international human rights law and international humanitarian law, constituting war crimes and crimes against humanity, committed since 2003. ${ }^{29}$ No existence of genocidal state policy was found; however, the ICID recognised that individuals may commit acts with genocidal intent to be determined by courts. ${ }^{30}$ War crimes perpetrated by non-state armed groups were found, albeit not committed in a systematic or widespread pattern. ${ }^{31}$ Thus, the UN Security Council referred the situation in Darfur to the ICC. This led to cases involving leaders of the parties to the armed conflict, prominently including President al-Bashir, for war crimes, crimes against humanity and genocide. The evidence relied on to issue arrest warrants against al-Bashir concerns crimes committed up to July 2008. However, the ICC prosecutor has denounced ICC Statute crimes attributed to state actors in later reports to the UN Security Council. In her June 2016 report, the prosecutor denounced the continuing deterioration of the security situation in Darfur and aerial attacks against civilians. ${ }^{32}$

The Human Rights Council (HRC)-mandated High Level Mission (2007), and the UN Office of the High Commissioner for Human Rights (UNOHCHR) (2015) documented gross and systematic violations of international humanitarian law and international human rights law (war crimes and crimes against humanity) allegedly perpetrated for several years mainly by state actors. ${ }^{33}$ Human Rights Watch also reported recent serious abuses. ${ }^{34}$

In 2004 the African Commission on Human and Peoples' Rights (African Commission) denounced the commission of mass atrocities mainly by state actors in Darfur. ${ }^{35}$ However, apparently it has not denounced mass atrocities in Darfur. ${ }^{36}$ In turn, the PSC apparently has not closely co-operated with the African Commission's fact finding. This affects the matrix of implementation of article $4(h)$, as the AU and the PSC would benefit from factual information gathered by the African Commission to authorise military intervention. This deficit was partially corrected by the 2013 joint report of the AU and UNOHCR

29 Report of the ICID to the UN Secretary-General, 25 January 2005 paras 630-638.

30 Report of the ICID (n 29 above) paras 640-642.

31 Report of the ICID para 639.

32 Twenty-third report, 9 June 2016 para 15.

33 Report of the High-Level Mission on the Situation of Human Rights in Darfur Pursuant to Human Rights Council Decision S-4/101, A/HRC/4/80, 9 March 2007 para 76; Report of the UNOHCHR on Impunity and Accountability in Darfur for 2014, August 2015 paras 73-74.

34 HRW World Report 2016, Sudan, Events of 2015 (2016), https://www.hrw.org/ world-report/2016/country-chapters/sudan\#399c55 (accessed 1 November 2016).

35 Report of the African Commission's Fact-Finding Mission to the Republic of Sudan in the Darfur Region, EX.CL/634 (XI), 8-18 July 2004 paras 107-110 \& 120-123.

36 Concluding Observations and Recommendations on the 4th and 5th Periodic Report of the Republic of Sudan, 12th extra-ordinary session of the African Commission on Human and Peoples' Rights, 29 July-4 August 2012. 
which documented serious abuses. ${ }^{37}$ Nevertheless, three years later no updated fact-finding report has been released.

As far as Libya is concerned, under HRC Resolution S-15/1 (2011), ${ }^{38}$ the International Commission of Inquiry to investigate alleged violations of international humanitarian law in Libya (ICIL) was set up and delivered reports before and after the fall of the Gaddafi regime. In 2011 the ICIL found that most crimes against humanity and war crimes were committed by Gaddafi's government forces. ${ }^{39}$ Conversely, in 2012 the ICIL focused on war crimes and crimes against humanity committed by the Thuwar (anti-Gaddafi forces). ${ }^{40}$ This difference reflected the shift of power in Libya and demonstrated that mass atrocities continued after Gaddafi's death. In turn, the African Commission and the African Court on Human and Peoples' Rights (African Court) in the Libya case referred to ongoing and imminent mass atrocities in Benghazi and other locations in Libya (during the Gaddafi regime), and the African Court ordered Libya to adopt provisional measures. ${ }^{4}$

As of 2016, the UNOHCHR reported that several actors in the ongoing Libyan armed conflict continued to commit war crimes and crimes against humanity. ${ }^{42}$ These include state actors (mainly the Libyan National Army); armed groups (Libya Dawn affiliates included); ISIL-affiliated armed groups; and tribal armed groups. ${ }^{43}$ Several actors have perpetrated mass atrocities since 15 February 2011. This date marks the start of the ICC's temporal jurisdiction over Libya under UN Security Council Resolution 1970 (2011). ${ }^{44}$ Pre-Trial Chamber I issued arrest warrants against Gaddafi, Saif Al-Islam Gaddafi and Al-Senussi for crimes against humanity (murder and persecution).

The Government of National Accord was formed following the agreement adopted on 17 December 2015 amid UN-backed negotiations. However, as of November 2016, Libya is still being affected by armed conflicts ${ }^{45}$ and related international crimes. In her November 2016 report to the UN Security Council, the ICC prosecutor denounced large executions committed by ISIL, civilian

37 UN, UNAMID, AU, UNOHCHR Human Rights Situation in Darfur in 2013, November 2014.

38 HRC Resolution S-15/1, Situation of Human Rights in the Libyan Arab Jamahiriya, A/HRC/S-15/1, 25 February 2011 para 11.

39 Report of the ICIL, A/HRC/17/44, 1 June 2011 7-8.

40 Report of the ICIL, A/HRC/19/68, 8 March 2012 para 11.

41 ACHPR/CHAIR/AfCHPR/108.11; African Court African Commission on Human and Peoples' Rights $v$ Great Socialist People's Libyan Arab Jamahiriya Application 004/ 2011, Order for Provisional Measures, 25 March 2011, paras 13, 22 \& 25.

42 Investigation by the UNOHCHR on Libya, Report of the UNOHCHR, A/HRC/31/47, 15 February 2016 paras 60-64.

43 As above.

44 S/RES/1970 (2011), 26 February 2011 para 4.

45 Armed Conflict Location and Event Data Project, 'Libya - October 2016 Update' http://www.crisis.acleddata.com/libya-october-2016-update/ (accessed 15 November 2016). 
deaths as a consequence of indiscriminate air strikes, and other atrocities perpetrated by all parties to the conflict. ${ }^{46}$ Major human rights non-governmental organisations (NGOs) confirmed that international crimes were still being perpetrated in Libya. ${ }^{47}$

\section{Target state unwilling or unable to stop mass atrocities}

Neither article 4(h) of the AU Constitutive Act nor article 4(j) of the PSC Protocol explicitly requires that the target state must be unwilling or unable to stop mass atrocities as a condition for the AU to authorise military intervention. However, the Pretoria Principles and scholars refer to such a requirement. According to the Principles:

4 Article 4(h) allows the AU to protect populations at risk of war crimes, genocide and crimes against humanity if the target state is unable or unwilling to discharge its primary responsibility to protect the fundamental rights of its citizens.

9 [T]he AU Assembly should consider the inability or unwillingness of the national government to protect its population from mass atrocities ... where a state violates the fundamental rights of its own citizens, or tolerates or fails to stop mass atrocities within its territory, the $A U$ is authorised by article $4(h)$ to intervene to prevent or halt mass atrocities...

Additionally, the Pretoria Principles provide:

$15[\mathrm{~T}]$ he $\mathrm{AU}$ should also ensure that member states respect their legal obligations to bring perpetrators of genocide to justice.

16 The AU should exert peer pressure on $A U$ member states to end violations where systematic patterns of human rights and humanitarian law violations are revealed, and encourage member states to enact laws to prevent mass atrocity crimes and punish the perpetrators of these crimes in the domestic group.

Scholars have considered that the target state must be unwilling or unable to stop mass atrocities as a condition to implement military intervention under article $4(\mathrm{~h}) .{ }^{48}$ The target state is primarily responsible for protecting its population. Its unwillingness or inability to fulfil this responsibility is a condition for article $4(\mathrm{~h})$ intervention, 'in which case such responsibility shifts to the $\mathrm{AU}^{\prime} .{ }^{49}$ Accordingly, when an AU member state is unable or unwilling to protect its population within its borders from mass atrocities, the AU should assume this

46 Twelfth Report, 9 November 2016 paras 13-17 \& 26.

47 HRW World report 2016, Libya, events of 2015 (2016), https://www.hrw.org/worldreport/2016/country-chapters/libya (accessed 26 June 2016).

48 Eg, Kuwali \& Viljoen (n 18 above) 342-344; T Kabau 'The responsibility to protect and the role of the regional organisations: An appraisal of the African Union's interventions' (2012) 4 Goettingen Journal of International Law 4990.

49 CB Murungu 'International crimes that trigger article 4(h) intervention' in Kuwali \& Viljoen (n 4 above) 7081. 
responsibility. ${ }^{50}$ Generally, when a state is unable or unwilling to protect its own nationals, the international community is expected to assume the residual responsibility under the responsibility to protect. $^{51}$ The responsibility to protect populations from mass atrocities is primarily placed on the territorial state, but permits collective external intervention as a last resort in case the territorial state fails in this regard. ${ }^{52}$ Sovereignty entails responsibility and, thus, non-intervention is subject to the fulfilment by the target state of its duty to protect its own population. ${ }^{53}$

An inability or unwillingness to prevent or stop mass atrocities may be inferred from diverse factors. Among others, the sources examined suggest the need for a close consideration of the systematic and/or widespread ongoing and protracted commission of international crimes in Darfur and Libya. 'Unwillingness' is present when state agents and/or their proxies have committed serious abuses and there is impunity. This has taken place in Libya and, especially, in Darfur (Sudan). In turn, 'inability' mainly concerns the incapacity of the target state to protect its population from mass atrocities. This has arguably been present in Darfur (Sudan) and, especially, in Libya. As examined, diverse sources evidence the commission of mass atrocities by state and non-state actors in Darfur and Libya. The absence of and/ or serious deficits in accountability mechanisms in Sudan and Libya are also examined to demonstrate that these states have been unwilling and/or unable to fulfil their obligation to protect their populations from mass atrocities.

Moreover, the impact of article 46Abis of the so-called Malabo Protocol (not yet in force), ${ }^{54}$ which grants immunity to AU sitting heads of states and high-level officials from prosecution at the prospective AU African Court of Justice and Human Rights, evidences 'unwillingness' to investigate those allegedly most responsible for mass atrocities in Africa. Article 46Abis impacts on the implementation of article $4(\mathrm{~h})$ because criminal prosecution, as a non-military measure, is precluded. Thus, the need for military intervention as last resort would arguably increase. Also, article 46Abis could be conveniently invoked by African leaders to justify their (potential) reluctance to co-operate with the implementation of article $4(\mathrm{~h})$. As

50 D Kuwali 'From stopping to preventing atrocities. Actualisation of article 4(h)' (2015) 24 African Security Review 243 249; L Sunga 'The role of humanitarian intervention in international peace and security: Guarantee or threat?' in $\mathrm{H}$ Kochler (ed) The use of force in international relations: Challenges to collective security (2006) 41; UN General Assembly (n 8 above).

51 Kabau (n 48 above) 66; K Kindiki Intervention to protect civilians in Darfur: Legal dilemmas and policy imperatives (2007) 6.

52 G) Evans The responsibility to protect: Ending mass atrocity crimes once and for all (2008) 141 144; HIPPO Report (n 7 above) paras 55 \& 202-203.

53 Stahn (n 10 above) 111-114; Kabau (n 48 above) 53.

54 Protocol on Amendments to the Protocol on the Statute of the African Court of Justice and Human Rights, AU Assembly, AU Doc Assembly/AU/Dec.529(XXIII), 27 June 2014. 
far as Darfur is concerned, the ICID found in 2005 that Sudan's measures to address the crisis had been 'grossly inadequate and ineffective', which had led to total impunity, and that the Sudanese system was unable or unwilling to address the crisis. ${ }^{55}$ In 2013 , the UN and the AU jointly pointed out that impunity 'remained a major concern', and that state inaction was caused by a lack of political will or capacity. ${ }^{56}$ In $2007^{57}$ and $2015^{58}$ respectively, the UN High-Level Mission on Darfur and the UNOHCHR reached similar findings and concluded that Sudanese justice mechanisms had been negligible, regarding accountability or redress, and had mostly ceased to exist. The national system failed to impact on 'combatting impunity and strengthening accountability' ${ }^{59}$ Apparently, this situation remains. ${ }^{60}$

Sudan's unwillingness or inability is also evidenced by its very uncooperative and obstructionist position to implement the ICC arrest warrants. The ICC prosecutor has reported about this situation. ${ }^{61}$ Sudan's co-operation ended when the ICC issued arrest warrants against state actors (2007), and worsened when al-Bashir was indicted (2008 and 2009). ${ }^{62}$ In 2016, the ICC prosecutor reported to the UNSC that the Sudanese judicial system was 'unable' or 'unwilling' to address international crimes committed in Darfur, ${ }^{63}$ which the Chambers had already found. ${ }^{64}$

As far as Libya is concerned, the ICIL found an absence of governmental action to address mass atrocities in June 2011 (before Gaddafi's fall). ${ }^{65}$ As of late 2016, the situation on the ground reveals mainly an 'inability' to stop mass atrocities in Libya. Despite some recent efforts, discussed later, no effective central government has been in place in Libya since Gaddafi's fall. There have been factional governments with different levels of international recognition and internal legitimacy. Libya has been qualified as a failed or lawless state, as the country is still divided among competing armed groups (including two rival parliaments and three governments) that have control over territory and population amid a lack of institutional framework. ${ }^{66}$ This power vacuum goes to the heart of 'inability' and

55 ICID (n 29 above) 5-6.

56 UN/AU (n 37 above) paras $106 \& 109$.

57 UN High-Level Mission on Darfur (n 33 above) paras 46-49.

58 UNOHCHR (n 33 above) para 68.

59 UNOHCHR para 72.

60 See HRW (n 34 above).

61 Eg Twenty-third Report (n 32 above) para 17.

62 Seventh Report, 13 May 2014 para 30.

63 Twenty-third report (n 32 above) para 17.

64 Al-Bashir Decision on the Prosecutor's Request for a Finding of Non-Compliance Against the Republic of the Sudan, 9 March 2015, ICC-02/05-01/09-227 11.

65 ICIL (n 39 above) 8.

66 The Economist 'Libya: The next failed state' 10 January 2015, http:// www.economist.com/news/leaders/21638122-another-font-global-mayhem-emer gingnot-helped-regional-meddling-and-western (accessed 7 November 2016); 
legality and strengthens the need for military intervention by the AU similar to the UN Security Council intervention in Somalia.

The situation regarding Libyan accountability mechanisms confirms and illustrates this inability. In March 2012, the ICIL found deficient accountability mechanisms, and no functioning court system to hold perpetrators accountable, to be considerable challenges to prosecuting violations. ${ }^{67}$ In 2016, the UNOHCHR stated that the 'justice system has been significantly compromised by the security situation and structural weaknesses' ${ }^{68}$ The Sudanese justice system lacks the means or capacity to conduct prompt, independent and credible investigations or prosecute those responsible in a form consistent with human rights. ${ }^{69}$ In 2016 Human Rights Watch found that the criminal justice system had collapsed or was dysfunctional. ${ }^{70}$

Libya's past and present unwillingness or inability is also evidenced by its relationship with the ICC. The ICC prosecutor has found no genuine national investigation or prosecution. ${ }^{71}$ The prosecutor requested the immediate transfer of Saif Gaddafi to the ICC. However, as the prosecutor reported to the UN Security Council in November 2016, Libya is unable to do so as Gaddafi remains outside the control of the Government of National Accord (after having been held prisoner by the Abu-Bakr al-Siddiq Battalion) and as the unstable security situation persists. ${ }^{72}$ Pre-Trial Chamber I had made a finding of Libya's non-compliance. ${ }^{73}$ This illustrates Libya's current inability to stop mass atrocities.

Finally, when examining the situations in Darfur ${ }^{74}$ and Libya, ${ }^{75}$ several scholars have found an unwillingness and/or inability of Sudan and Libya to protect their nationals from mass atrocities. Regarding ICC prosecution triggered by UN Security Council resolutions, Sudan, Libya and all other UN member states are obligated to co-operate

A Kuperman 'Obama's Libya debacle: How a well-meaning intervention ended in failure' (2015) 94 Foreign Affairs 66-77; BBC 'Why is Libya so lawless?' 14 September 2016 http://www.bbc.com/news/world-africa-24472322 (accessed 15 November 2016).

67 ICIL (n 40 above) paras 101-109.

68 UNOHCHR (n 42 above) para 66.

69 UNOHCHR para 70.

$70 \mathrm{HRW}$ (n 47 above).

71 First Report, 4 May 2011 para 3; Seventh Report (n 62 above) para 20.

72 Twelfth Report 10 December 2010 paras 3-8 \& 13.

73 Gaddafi Decision on the Non-Compliance by Libya with Requests for Cooperation by the Court and Referring the Matter to the United Nations Security Council, 10 December 2014 ICC-01/11-01/11-577 16.

74 Eg, J Traub Unwilling and unable: The failed response to the atrocities in Darfur (2010); Kabau (n 48 above) 66; FK Abiew 'Article 4(h) intervention: Problems and prospects' in Kuwali \& Viljoen (n 4 above) 109 114; K Mills International responses to mass atrocities in Africa. Responsibility to protect, prosecute and palliate (2015) 184204.

75 Eg, C Sahn 'Libya, the International Criminal Court and complementarity. A test for "shared responsibility"' (2012) 10 Journal of International Criminal Justice 325 326; Murungu (n 49 above) 81; Kuwali \& Viljoen (n 18 above) 342; Kuwali (n 50 above) 252 . 
with the ICC, regardless of their status as parties to the ICC Statute, as this obligation stems from the UN Charter. ${ }^{76}$

\section{Article 4(h) military intervention as the last available resource or measure}

Article 4(h) makes express mention of 'to intervene', which also appears in article 4(j) of the PSC Protocol. According to article 23(2) of the AU Constitutive Act,

any member state that fails to comply with the decisions and policies of the Union may be subjected to other sanctions, such as the denial of transport and communication links with other member states, and other measures of a political and economic nature to be determined by the Assembly.

According to the Pretoria Principles:

4 Where diplomacy and other peaceful means have failed, the AU may use force to protect populations at risk of mass atrocities. Therefore, it is coercive measures, in particular, military force, that require the decision of the AU Assembly under article 4(h).

5 Intervention on the basis of article 4(h) is an exceptional measure in the face of grave circumstances that are beyond non-coercive measures and so require military option as a last resort.

... article 23(2) ... provides for political and economic sanctions and denial of transport and communication against errant states, article $4(\mathrm{~h})$ recognises that there are limits to non-violent means in stopping mass atrocities, and the only realistic means can be military intervention.

According to a textual interpretation, article 4(h) intervention only consists of coercive measures other than sanctions, that is, military intervention, since article 23(2) provides for sanctions. ${ }^{77}$ This interpretation is also consistent with the fact that the $\mathrm{AU}$ can engage in non-coercive measures such as preventive diplomacy, dialogue, conflict resolution, good offices and deployment of monitors. 78 Therefore, article 4(h) adds military intervention as a measure of last resort. ${ }^{79}$ In light of a purposive interpretation, the sort of intervention needed to neutralise the gravity of the international crimes listed in article 4(h) requires very intrusive means, namely 'incisive and purposeful military action', to prevent harm resulting from international crimes and akin to 'peace enforcement'. ${ }^{80}$

The Pretoria Principles establish that 'accountability through criminal prosecution to deter potential perpetrators, for example by

76 Al-Bashir Decision on the Prosecution's Application for a Warrant of Arrest, 4 March 2009 ICC-02/05-01/09-3 paras 242-249; Stahn (n 75 above).

77 Kuwali \& Viljoen (n 18 above) 341.

78 As above.

79 As above; Kuwali (n 50 above) 252.

80 Kuwali \& Viljoen (n 18 above) 341. 
arresting perpetrators, may also be part of an article 4(h) intervention'. ${ }^{81}$ However, it is argued that criminal prosecution does not form part of an article 4(h) intervention. First, scholars have considered that criminal prosecution, alongside diplomatic and economic sanctions, is not part of military intervention. ${ }^{82}$ Second, the establishment by the UN Security Council of the ICTY and ICTR as peaceful measures (non-military intervention) under article 41 of Chapter VII of the UN Charter exemplifies that criminal prosecution falls short of article 4(h). Third, the AU has refrained from invoking or referring to article $4(\mathrm{~h})$ in its non-military interventions as the $A U$ intended article $4(h)$ to be invoked only when the AU wishes to use military force and not criminal prosecutions. The Ezulwini Consensus, which is the most influential and authoritative $A U$ document relating to the character and intended purpose of article 4(h), exemplifies the $\mathrm{AU}^{\prime}$ s above-mentioned position: 83

Article 51 of the UN Charter ... authorise[s] the use of force only in cases of legitimate self-defence ... article 4(h) [of the Constitutive Act] authorises intervention in grave circumstances ... Consequently, any recourse to force outside the framework of article $51 \ldots$ and article $4(\mathrm{~h}) \ldots$ should be prohibited.

Lastly, the ICISS found that (international) criminal prosecutions fall 'short of military intervention'. ${ }^{84}$ Additionally, the HIPPO Report, ${ }^{85}$ the Outcome Document ${ }^{86}$ and various UN Secretary-General reports on the implementation of the responsibility to protect ${ }^{87}$ have not regarded criminal prosecution as part of military intervention.

Punitive actions, particularly sanctions under article 23(2) of the AU Constitutive Act, may relate to the process of implementing article 4(h). These sanctions are necessary to be undertaken prior to the implementation of article 4(h), which consists of military intervention as a measure of last resort. Indeed, the exhaustion of all possible nonmilitary measures, both sanctions and non-punitive measures, is a condition precedent to proceeding with the application and implementation of article 4(h). Additionally, it may be argued that, once the implementation of article $4(\mathrm{~h})$ is in motion, a continuous follow-up to potential article 23(2) measures must be conducted to see whether, if possible, an article 4(h) military intervention is no longer necessary or to stop its implementation. Considering the above, it is argued that, in the case of Darfur, several measures, other

81 Principle 8.

82 Eg Kuwali (n 14 above) 34; Kabau (n 48 above) 59; E Yemisi Omorogbe 'Can the African Union deliver peace and security?' (2011) 16 Journal of Conflict and Security Law 3541.

83 AU Executive Council 'The Common African position on the proposed reform of the United Nations (the Ezulwini Consensus)' 7th extraordinary session 7-8 March 2005, Addis Ababa, Ethiopia, Ext/EX.CL/2 (VII) 6.

84 ICISS Report (n 6 above) 8.

85 HIPPO Report (n 7 above) para 90.

86 UN General Assembly (n 8 above) paras 77-80 \& 138-140.

87 Eg Report (n 9 above) paras 17-19 \& 53-54. 
than military intervention, have already and unsuccessfully been implemented by the AU, the UN and ICC to stop mass atrocities and to prevent further violence since the start of the ongoing violations in 2003.

First, under article 4(j) of the AU Constitutive Act, which grants AU member states the right to request intervention by the $A U$ to restore peace and security, the AU Mission in Sudan (AMIS) was created in 2004. However, this constituted an inadequate peacekeeping force which was deployed with Sudan's consent. AMIS was not an enforcement (article 4(h)) but a consensual action resulting from the agreement between the PSC and all parties to the conflict. ${ }^{88}$ Due to the increase in hostilities and international crimes, the UN Security Council authorised the establishment of a stronger hybrid joint operation with the AU: the Hybrid Mission in Darfur (UNAMID). UNAMID constituted a compromise between Sudan, which opposed UN intervention, and the UN, which suggested expanding the UN Mission in Sudan. Nevertheless, UNAMID was only a peacekeeping and not an enforcement force. ${ }^{89}$ Hence, UNAMID was unable to stop international crimes. UN Security Council Resolution 1769 established that UNAMID forces would be led under 'principles of peacekeeping'. Whereas the AU intervened on consensual basis (Sudan's consent) and never changed its mandate, the Security Council issued Chapter VII Resolutions that may enable enforcement action. ${ }^{90}$ Nevertheless, the UN arguably contradicted its enforcement mandate by seeking the consent of Sudan despite the direct involvement in mass atrocities of the latter. ${ }^{91}$ These contradictions and related problems of impartiality, co-operation and state consent are important reasons why the Darfur crisis should have been and should still be tackled by a robust and well-developed enforcement action to stop the mass atrocities. ${ }^{92}$ UNAMID has been mostly ineffective in protecting civilians from violence, hampered by Sudan's denial of access to conflict areas. ${ }^{93}$

Second, by means of Chapter VII Resolutions, the UN Security Council has ordered UN member states to implement targeted sanctions against specific individuals or groups that are suspects of being involved in mass atrocities in Darfur. These sanctions have included bans on travel and transit restrictions; the freezing of funds, financial assets, and economic resources; and arms embargoes. ${ }^{94}$ Individuals and entities that planned, sponsored or participated in attacks threatening the stability in Darfur have been or are to be

88 Abiew (n 74 above) 115.

89 As above; D William 'African Union mission in Sudan' (2006) 13 International Peacekeeping 168 175-177.

90 Kabau (n 48 above) 68.

91 Kabau 69.

92 As above.

$93 \mathrm{HRW}$ (n 34 above).

94 Eg, S/RES/1591 (2005), 29 March 2005 para 3; S/RES/2200 (2015), 12 February 2015 paras 6-9; S/RES/2265 (2016), 10 February 2016 para 13. 
sanctioned. 95 These measures are called 'smart sanctions', as they impose restrictions on specific individuals or organisations rather than on entire populations, and under 'black lists' prepared by the UN Security Council Sanctions Committee. Targeted sanctions are more advisable because indiscriminate restrictions on the human rights of entire populations are to be avoided.

Third, the UN Security Council via Chapter VII Resolution 1593 found the Darfur crisis to be a threat to international peace and security, and triggered the ICC's jurisdiction (referral) to investigate mass atrocities perpetrated in Darfur since 1 July 2002, when the ICC Statute entered into force. ${ }^{96}$ Arrest warrants have been issued against those allegedly most responsible, including al-Bashir, for international crimes that constitute 'grave circumstances' under article 4(h). Under the UN Security Council's referral, state parties and non-state parties to the ICC Statute are obliged to co-operate with the ICC. ${ }^{97}$ However, this obligation was breached when some African state parties and non-state parties to the ICC Statute did not arrest al-Bashir during his official visits to those states. The former and current ICC prosecutors have reported this to the UN Security Council.

Once consensual intervention, peacekeeping and other measures (including international criminal prosecution) proved to be ineffective to stop mass atrocities in Darfur, the AU should have accepted and should accept that forceful, military intervention under article 4(h) was, and arguably still is, the only measure remaining.

As far as Libya is concerned, the UN Security Council timely authorised intervention during indiscriminate attacks launched in March 2011 by the Gaddafi regime against the civilian population. Notwithstanding the 2011 NATO military intervention, international crimes are still being committed by diverse actors amid the volatile situation in Libya. This may constitute a scenario for a second military intervention to be implemented by the AU. Non-military intervention measures have already been implemented by the UN, the AU and the ICC. These measures are discussed to illustrate that article 4(h) military intervention should have been applied and arguably should still be applied as a measure of last resort.

First, in a Communiqué dated 23 February 2011, the PSC condemned the excessive use of force against civilians and the loss of lives, called for an end to the violence and repression, and supported the democratic aspirations of the Libyan people. Nevertheless, unlike in the case of the Arab League, the AU did not suspend Libya's AU membership, nor did the $A U$ impose sanctions on the Gaddafi regime. As examined later, the $A U$ indeed criticised the NATO-led

95 Eg S/RES/2265 (2016), 10 February 2016 para 19.

96 S/RES/1593 (2015) para 1.

97 D Akande 'The effect of Security Council resolutions and domestic proceedings on state obligations to co-operate with the ICC' (2012) 10 Journal of International Criminal Justice 299-324. 
intervention. The AU decided to seek a peaceful solution and rejected foreign intervention, including military intervention. ${ }^{98}$ The $\mathrm{AU}$ called for an immediate ceasefire and political reforms. ${ }^{99}$ The National Transitional Council rejected this since Gaddafi's resignation was excluded. ${ }^{100}$ In September 2011, the UN Security Council established a UN Support Mission in Libya. ${ }^{10 \prime 1}$ The UN Security Council welcomed the Libyan Political Agreement to form the Government of National Accord (17 December 2015), which resulted from UN-backed negotiations, and also endorsed the Rome Communiqué (13 December 2015) to support the Government of National Accord as the sole legitimate Libyan government based in Tripoli. ${ }^{102}$ However, as discussed, armed conflicts, a lack of control over the whole Libya and mass atrocities still persist late in 2016.

Second, besides the authorisation of military intervention to protect civilians under threat of attack, especially in Benghazi, ${ }^{103}$ the UN Security Council ordered a no-fly zone to protect these people. 104 Additionally, the Arab League's call for the imposition of a no-fly zone over Libya to protect civilians was pivotal to raising support for external military intervention. ${ }^{105}$

Third, the UN Security Council via Chapter VII Resolutions has requested states to implement its Sanctions Committee's targeted sanctions against specific individuals or organisations involved in atrocities in Libya. ${ }^{106}$ Bans on travel, the freezing of funds, financial assets and economic resources, an arms embargo, a ban on flights and the prevention of illicit oil exports have been ordered. ${ }^{107}$ The AU and its member states are obliged to implement these sanctions. However, unlike the UN or the European Union, ${ }^{108}$ the AU has not issued similar sanctions.

Fourth, the UN Security Council referred the situation in Libya to the ICC for investigation of crimes under ICC jurisdiction allegedly committed since 15 February 2011. ${ }^{109}$ The ICC has considered one

$98 \mathrm{AU}$ 'Communiqué of the 265th Meeting of the Peace and Security Council' 10 March 2011 PSC/PR/COMM.2 (CCLXV).

$99 \mathrm{AU}$ 'Official Presentation by the $\mathrm{AU}$ to the Libyan Parties of a Proposal on a Framework Agreement for a Political Solution to the Crisis in Libya' Press Release, 1 July 2011; UN Doc S/2011/455, 26 July 2011, 'AU Proposals to the Libya Parties for a Framework Agreement on a Political Solution to the Crisis in Libya' para 8.

100 EY Omorogbe 'The African Union, responsibility to protect and the Libyan crisis' (2012) 59 Netherlands International Law Review 141161.

101 S/RES/2009 (2011), 16 September 2011 para 12.

102 S/RES/2259 (2015), 23 December 2015 paras $1 \& 3$.

103 S/RES/1973 (2011), 17 March 2011 para 4.

104 n 103 above, para 6.

105 Abiew (n 74 above) 118.

106 S/RES/1970 (2011) paras 22-23.

107 Eg, S/RES/1973 (2011) paras 13-23; S/RES/2278 (2016), 31 March 2016 paras 1-4 \& 6-10.

108 Eg, Council Decision 2011/137/CFSP, 28 February 2011, OJ 2011 L 58/53.

109 S/RES/1970 (2011) para 4. 
case, originally involving three suspects, for crimes against humanity (murder and persecution). ${ }^{110}$ The case against Muammar Gaddafi was withdrawn after his death (20 October 2011) and the case against Abdullah Al-Senussi was declared inadmissible. The AU rejected the ICC arrest warrants as it found these to seriously compromise a political solution to the crisis. ${ }^{111}$ This obstructionist position of the $\mathrm{AU}$ is criticised as the AU-led efforts have not yielded a real solution to the ongoing Libyan crisis.

Fifth, on 25 March 2011, the African Court issued provisional orders $^{1} 12$ against Libya to immediately refrain from actions resulting in the loss of life or the violation of physical integrity. ${ }^{113}$ These measures were ordered considering extreme gravity, urgency, and risks of irreparable harm. ${ }^{114}$ However, since the AU opposed any military intervention in Libya, it did not enforce these orders by forceful intervention. ${ }^{115}$ This has been criticised as the findings of the African Court should have prompted the AU to apply and implement article 4(h).

\section{AU Assembly takes the decision to intervene}

Article 4(h) of the AU Constitutive Act mentions 'the right of the Union to intervene in a member state pursuant to a decision of the Assembly'. Article 4(j) of the PSC Protocol includes the same provision. Intervention under article $4(\mathrm{~h})$ requires a decision of the $A U$ Assembly of Heads of State and Government, as highlighted by the Pretoria Principles. ${ }^{116}$ Whether this intervention is a right, as indicated by article 4(h), or may be purposely interpreted as an obligation is, to an important extent, clarified by the Pretoria Principles:

6 The 'right' in article 4(h) implies a legal entitlement or prerogative which is compatible with the notion of sovereignty as responsibility. This 'right' should as far as feasible be interpreted to imply a duty to intervene to prevent or halt mass atrocities.

Importantly, the Pretoria Principles explained the rationality that the AU Assembly should follow when deciding to intervene: 'The AU must prioritise the imperative to save lives over technical or overly legalistic ascertainment of the commission of war crimes, genocide and crimes against humanity. ${ }^{117}$

110 See Situation in Libya, ICC-01/11 https://www.icc-cpi.int/libya (accessed 25 June 2016).

111 Abiew (n 74 above) 118.

112 Art 27(2) Protocol to the African Charter on Human and Peoples' Rights on the Establishment of an African Court on Human and Peoples' Rights, adopted 9 June 1998, entered into force 25 January 2004.

113 African Court (n 41 above) para 25.

114 African Court para 22.

115 Kabau (n 48 above) 72.

116 Principle 4.

117 Principle 10. 
To apply article 4(h), the AU Assembly is expected to proceed in a two-phase inquiry. ${ }^{118}$ First, it must be determined that war crimes, genocide and/or crimes against humanity have been, are being or are very likely to be perpetrated based on a number of fact-finding and judicial sources. ${ }^{19}$ Second, when exercising its discretion to intervene, the $\mathrm{AU}$ should draw attention to implied factors under article $4(h) .{ }^{120}$ These factors include the commission of crimes by state actors; state collusion with non-state actors; a state's inability to stop mass atrocities; the AU's prior efforts; the availability of military capacity and resources; actions and approaches undertaken at the international - mainly the UN Security Council - and sub-regional levels; and a cost-benefit analysis, ${ }^{121}$ including an assessment of the loss of life and other consequences related to intervention.

Bearing in mind the large volume of evidence demonstrating mass atrocities in Darfur and Libya involving, inter alia, state actors, and also the unwillingness and/or inability of the Sudanese and Libyan governments, the lack of military intervention by the AU should be critically examined. The AU may have believed that there were objective factors or indicators for military intervention but, in exercising its discretion, the AU decided not to authorise military action. ${ }^{122}$ The lack of application of article $4(\mathrm{~h})$ by the AU Assembly concerning Darfur and Libya reveals the AU's unwillingness or inability to tackle this issue. Indeed, rather than taking the decision to militarily intervene in Darfur or Libya, the AU Assembly has opposed foreign military intervention.

The PSC can potentially play a pivotal part in the matrix of application and implementation of article 4(h) in Darfur and Libya. The PSC is a collective security and early-warning arrangement organ concerning conflict and crisis situations in Africa. ${ }^{123}$ It may recommend that the $\mathrm{AU}$ Assembly intervenes. ${ }^{124}$ However, the PSC's role is recommendatory, unlike the AU Assembly's decision-making role. Although some practice of the PSC has suggested the use of force to save lives, ${ }^{125}$ the AU Assembly has yet to apply and implement article 4(h). Nevertheless, should the PSC actively exercise its recommendatory role, it may become a key body to trigger article 4(h). Moreover, the PSC Protocol grants large powers upon the PSC

118 Kuwali \& Viljoen (n 18 above) 343-344.

119 As above; Kuwali (n 50 above) 257.

120 Kuwali \& Viljoen (n 18 above) 343-344; Kuwali (n 50 above) 257.

121 As above.

122 K Akonor 'Assessing the African Union's right of humanitarian intervention' (2010) 29 Criminal Justice Ethics 157 165; Abiew (n 74 above) 118-119.

123 Art 1 PSC Protocol.

124 Art 7(1)(e) PSC Protocol.

125 Eg, concerning Somalia PSC Communiqué, 27 February 2013, PSC/PR/Comm (CCCLVII). 
to 'approve the modalities of intervention' by the AU following a decision adopted by its Assembly. ${ }^{126}$ The PSC may, thus, play a crucial role in the architecture of peace and security in Africa, which includes a continent-wide early warning system. ${ }^{127}$ Indeed, the intersection between human rights and conflict prevention evidences the role of the $\mathrm{AU}$ Commission (the functional body of the $A U$ ), particularly its Peace and Security Department, which arguably requires more experienced and professional human rights officers. ${ }^{128}$ The AU Assembly, as advised by the PSC, should apply article 4(h) in Darfur and Libya. To deploy military operations in Darfur and Libya, the PSC needs the co-operation of the AU for the African Standby Force $^{129}$ to effectively implement article $4(\mathrm{~h})$ on the ground.

In the matrix of implementation of article 4(h) and existent operational context of the AU, the African Commission's fact-finding powers may be crucial to inform both the AU Assembly and the PSC when deciding on the authorisation for and implementation of military intervention. Nevertheless, as far Darfur and Libya are concerned, the African Commission's fact-finding has arguably been limited, especially when compared to the UN fact-finding missions. The African Commission's fact-finding mission in Darfur in 2004 recommended that Sudan accept an international commission of inquiry to investigate mass atrocities in Darfur, and the role of state and non-state actors. ${ }^{130}$ However, the African Commission apparently no longer has undertaken fact-finding actions concerning Darfur. As far as Libya is concerned, other than the African Commission's participation in the Libya case (2011), the Commission has seemingly conducted no fact finding. The importance of the Commission's sustained fact finding, as compared to that of the UN, is the fact that the AU and PSC may regard it as more legitimate. The African Commission is not only a non-political body, but also an organ of the $\mathrm{AU}$. In addition, the Commission may bring cases (such as the Libya case) to be decided by the African Court. ${ }^{131}$ The African Commission can also bring cases of mass atrocities in Darfur and Libya to the attention of the AU Assembly ${ }^{132}$ and the PSC. ${ }^{133}$ Moreover, the African Commission may submit cases of 'emergency' (concerning Darfur and Libya) to the AU Assembly. ${ }^{134}$ Thus, the AU Assembly and PSC would have more AU sources to apply and implement article 4(h) in Darfur and Libya. AU member states could, therefore, hardly raise allegations of 'neo-colonialism' or interference in African matters.

126 Art 7(1)(f) PSC Protocol.

127 Art 12 PSC Protocol.

128 F Viljoen International human rights law in Africa (2012) 192.

129 Art 13 PSC Protocol.

130 African Commission (n 35 above) paras 137-138.

131 Art 5(1)(a) African Court Protocol.

132 Art 58(1) African Charter on Human and Peoples' Rights.

133 Viljoen (n 128 above) 196.

134 Art 58(3) African Charter. 
Furthermore, the PSC Protocol introduces a two-way synergetic exchange. The African Commission should provide the PSC with pertinent information, and the PSC should co-operate closely with the Commission and seek to involve the Commission in its activities by, for example, inviting the Commission to its discussions, or requesting the Commission to conduct studies or on-site missions on its behalf. ${ }^{135}$ Nonetheless, as far as Darfur and Libya are concerned, this has yet to materialise. The PSC's support of the African Commission to conduct fact-finding missions must take place.

As far as Darfur is concerned, the $A U$ has rejected forceful intervention and opted for other options previously examined. ${ }^{136} \mathrm{~A}$ PSC member state party to a matter before the PSC is prohibited from discussion and decision making on that matter. ${ }^{137}$ However, Sudan used its position within the PSC to block deliberations regarding Darfur. ${ }^{138}$ Since Sudan provided no consent, the AU was unwilling to intervene. ${ }^{139}$ The $\mathrm{AU}$ has not lobbied for forceful international intervention to stop mass atrocities in Darfur, ${ }^{140}$ nor has it undertaken a forceful intervention in terms of article $4(h) .{ }^{141}$ Furthermore, not only has the AU Assembly opposed the ICC arrest warrants against alBashir, but it has also, alongside the PSC, urged AU members not to co-operate with the ICC. ${ }^{142}$ Based on sources previously discussed, the above-mentioned first phase of the enquiry for the $A U$ to decide to intervene has been met. ${ }^{143}$ Thus, the position of the PSC/AU Assembly of blocking rather than respectively recommending or applying article $4(\mathrm{~h})$ military intervention is criticised. Indeed, although the $\mathrm{AU}$ denied allegations of genocide, it accepted that war crimes and crimes against humanity had been perpetrated. ${ }^{144}$

However, the above-mentioned second phase of the inquiry has militated against AU intervention because, arguably, certain circumstances, mainly related to implementation or 'implementability' problems, were present. These included Sudan's resistance; uncertainty regarding the position of the UN Security Council; ${ }^{145}$ the lack of an available African standby force; and the fact that the PSC

135 Viljoen (n 128 above) 195-196.

136 AU Doc PSC/AHG/Comm.(X), 25 May 2004 para 6; PSC/PR/Comm.(XIII), 27 July 2004; PSC/PR/Comm(XVII), 20 October 2004 paras 6-7; PSC/PR2(XIII), 20 October 2005.

137 Art 8(9) PSC Protocol.

138 PD Williams 'The Peace and Security Council of the African Union: Evaluating an embryonic international institution' (2009) 47 Journal of Modern African Studies 603 620; Omorogbe (n 82 above) 41.

139 Kabau (n 48 above) 60.

140 As above.

141 As above.

142 AU Doc Assembly/AU/Dec.245(XIII), 3 July 2009 para 10; AU Doc PSC/PR/Comm (CXCVIII), 21 July 2009 para 14.

143 Kuwali (n 50 above) 260.

144 Eg, Report of the African Union High-Level Panel on Darfur, AU Doc PSC/AHG/2 (CCVII).

145 See section 7 below. 
only started functioning in 2004 - the PSC Protocol entered into force on 26 December 2003. ${ }^{146}$ These factors were present during the early stages of the conflict in Darfur, and some remain. Nonetheless, the fact that the conflict, mass atrocities and impunity still continue should prompt the AU Assembly to authorise military intervention to be implemented on the ground by the African Standby Force, closely supported by the UN. Furthermore, the AU Assembly should be aware of the fact that the failure by the $A U$ to bring peace and security to Darfur affects the AU's legitimacy. Thus, it would be in the best interests of the AU to apply article $4(h){ }^{14}$

As far as Libya is concerned, the $\mathrm{AU}$ has expressed unease about and opposition to NATO military intervention. The AU Peace and Security Commissioner complained about the non-African actors' pursuit of their own agendas, which allegedly prevented the AU from promoting a peaceful settlement. ${ }^{148}$ The AU Assembly stated that the NATO-led intervention contradicted Resolution 1973, as it considered this intervention to be a threat to civilians, complicating the democratic transition. ${ }^{149}$ The $\mathrm{AU}$ Assembly also manifested its disappointment at the marginalisation of the AU. ${ }^{150}$ However, the AU should have participated in the implementation of the responsibility to protect the civilian population from mass atrocities, including support for the implementation of a no-fly zone. ${ }^{151}$

As far as the above-mentioned first phase of the enquiry is concerned, sources previously discussed have proved the perpetration of war crimes and crimes against humanity in Libya. Nevertheless, the AU did not apply article 4(h). Regarding the above-mentioned second phase of the enquiry, the Arab league called upon the UN Security Council to impose a no-fly zone over Libya. However, the AU refrained from doing so and, instead, the PSC adopted two decisions which the UN Security Council took over. These decisions were a roadmap to be followed by Libya to sort out the crisis, and the establishment of an AU High Level Ad Hoc Committee on Libya, constituted of five heads of state, alongside the Commission's Chairperson. ${ }^{152}$ After NATO's military intervention, this Committee confirmed its opposition to foreign military intervention. ${ }^{153}$ The $\mathrm{AU}$ also called for an African solution to solve the crisis in Libya. ${ }^{154}$

146 Kuwali (n 50 above) 260.

147 Abiew (n 74 above) 115; Omorogbe (n 82 above) 53.

148 A Maasho 'AU says non-Africans sidelining Libya peace plan' Reuters 26 April 2011.

$149 \mathrm{AU}$ Doc EXT/ASSEMBLY/AU/DEC/(01.2011), 25 May 2011 para 5.

150 n 149 above, para 8.

151 Kabau (n 48 above) 61.

152 Kuwali (n 50 above) 260.

153 Meeting of the AU High-Level Ad Hoc Committee in Libya, Nouakchott, Islamic Republic of Mauritania, 19 March 2011.

$154 \mathrm{M}$ du Plessis \& A Louw 'Justice and the Libyan crisis: The ICC's role under Security Council Resolution 1970' ISS Africa Briefing Paper (2011) 5. 
The second phase was compounded by internal and political divisions within the AU concerning Libya. There were different positions within the $A U$ regarding the recognition of the National Transitional Council (NTC) as the legitimate government of Libya. ${ }^{155}$ The AU did not formally recognise the NTC immediately after the death of Gaddafi. ${ }^{156}$ In any event, the prolonged continuation of international crimes and Libya's inability to address impunity constitute powerful factors that may guarantee article 4(h) intervention.

Indeed, some support related to potential military intervention given by the $A U$, or some of its members, may be inferred from the Libyan situation. The AU supported the UN Security Council no-fly zone via a PSC press statement. ${ }^{157}$ Moreover, as part of the strong international support for Resolution 1973, three AU member states, at the time non-permanent members of the Security Council, voted in favour of this resolution. ${ }^{158}$

The inaction of the AU Assembly regarding Darfur and Libya illustrates the tense and potentially-contradictory relationship between what is stated in article 4(h) and political factors (realpolitik considerations). The voting procedure at the AU Assembly, namely, decisions adopted by consensus or eventually by a two-thirds majority, ${ }^{159}$ has to an important extent enabled political considerations to prevail over legal criteria and abundant evidence. As discussed, the AU Assembly and the PSC, unfortunately, have disregarded legal and factual considerations for the sake of political considerations. The fact-finding powers of certain AU organs, particularly the African Commission, are not constrained by the AU Assembly's political decisions. However, the African Commission, especially when compared to the UN mechanisms, has exercised only limited fact finding regarding mass atrocities in Darfur and Libya. Therefore, the PSC and AU Assembly should actively co-operate with the African Commission's fact-finding initiatives.

\section{Need for authorisation by the UN Security Council}

Neither article 4(h) of the AU Constitutive Act nor article 4(j) of the PSC Protocol contains any explicit reference to the need for authorisation by the UN Security Council should the AU Assembly decide to apply article $4(\mathrm{~h})$. It is open to debate whether the AU requires this authorisation when relying on article $4(h)$ to undertake military intervention in an $\mathrm{AU}$ member state, notwithstanding the

155 Kuwali (n 50 above) 261.

156 AU Communiqué of the 297th Meeting of the Peace and Security Council, PSC/ $\mathrm{PR} / \mathrm{COMM} / 2$ (CCXCVII) para 4.

157 AU Doc PSC/PR/BR.1 (CCLXVIII), 23 March 2011.

158 UN Doc SC/10200, 17 March 2011.

159 Art 7(1) Constitutive Act. 
provisions of Chapter VII of the UN Charter. ${ }^{160}$ However, even those who question the need for this authorisation prior to an article 4(h) military intervention reckon that ex post facto authorisation by, or at least a lack of opposition on the part of the Security Council, is necessary. ${ }^{161}$ The predominant view is that article $4(\mathrm{~h})$ military interventions should be preceded by Security Council authorisation and that only if the Security Council remains unwilling or unable to act in the face of mass atrocities, the AU should exceptionally be able to intervene without prior authorisation. ${ }^{162}$ The most recent subregional African practice, that is, the practice of the Economic Community of Western African States (ECOWAS) and the Southern African Development Community (SADC), supports this. ${ }^{163}$ Moreover, state practice, ${ }^{164}$ scholars $^{165}$ and the ICISS Report ${ }^{166}$ support the notion that the decision to intervene militarily only falls on the UN Security Council as a matter of principle.

Furthermore, an important reason to seek Security Council authorisation before military intervention is to increase the likelihood of the successful implementation of article 4(h) on the ground. Even after the African Standby Force finally becomes fully operational, the deployment of military forces to overcome powerful armies, such as that of Sudan, requires the co-operation of the international community. Should the AU obtain the UN Security Council's ex ante consent, article 4(h) military intervention will have passed the test of legality and will gain legitimacy. Thus, UN member states would be expected to support the implementation of article 4(h) with material, military, financial and logistical support.

The Pretoria Principles clarify the fact that there should be authorisation by the UN Security Council unless the Council is unwilling or indecisive:

11 As a matter of legal requirement, the $\mathrm{AU}$ requires the authorisation of the UN Security Council for article 4(h) intervention. The UN Security Council has the responsibility to authorise the use of force in the implementation of article 4(h) intervention. Where the UN Security Council is unwilling or indecisive in authorising intervention, the conferment of the right to intervene on the $A U$ by member states of the $A U$ provides greater space for the AU to act in the face of war crimes, genocide and crimes against humanity on the continent.

160 See HIPPO Report (n 7 above) paras 199-209.

161 M Kunschak 'The role of the United Nations Security Council in the implementation of article 4(h)' in Kuwali \& Viljoen (n 4 above) 54 60-61.

162 Eg, Kuwali \& Viljoen (n 18 above) 344; Omorogbe (n 82 above) 41; Akonor (n 122 above) 157; G Amvane 'Intervention pursuant to article 4(h) of the Constitutive Act of the African Union without United Nations Security Council authorisation' (2015) 15 African Human Rights Law Journal 282-298.

163 Kuwali \& Viljoen (n 18 above) 344-345.

164 Focarelli (n 5 above) 203.

165 As above; Stahn (n 10 above) 120.

166 ICISS Report (n 6 above) para 6.5. 
The responsibility to protect civilians from mass atrocities when the state concerned is unwilling or unable to do so should, in principle, be borne by the international community as mainly channelled via the UN Security Council. The Pretoria Principles also suggest that '[s]hould peaceful means be inadequate and national authorities manifestly fail to protect their populations from mass atrocities, the international community should help the $\mathrm{AU}$ to intervene to stop the mass atrocities'. 167

The legal foundation of the Pretoria Principles quoted is found in article 53 of the UN Charter, namely, that '[n]]o enforcement action shall be taken under regional arrangements or by regional agencies without the authorisation of the Security Council'. ${ }^{168}$ Although it may be argued that article 4(h) requires no Security Council authorisation, article 53 of the UN Charter seems to subject military intervention by the $\mathrm{AU}$ to this authorisation. Additionally, article 103 of the UN Charter provides that, in case of a conflict between state obligations under the UN Charter and state obligations under any other treaty (the AU Constitutive Act), the former shall prevail.

Taking the above into account, it is argued that if the AU had decided to apply or decides to apply article 4(h) to stop or prevent further mass atrocities in Darfur and Libya, the UN Security Council would have given or should give the necessary authorisation.

As far as Darfur is concerned, the UN Security Council has considered and continues to consider the situation in Darfur as a threat to both international peace and security and regional stability, which prompted it to adopt Chapter VII measures. ${ }^{169}$ Security Council authorisation of military intervention is necessary based on legal considerations and challenges to implementation on the ground. To overcome the well-organised and strong military force of Sudan, external support is required to complement the limited military power of the AU. ${ }^{170}$ Thus, Security Council authorisation should be accompanied by financial, material, military and technical support. ${ }^{171}$ The AU could have sought Security Council authorisation to trigger article 4(h) military intervention in Darfur and, additionally, could have requested support by the international community to complement its resources in such intervention. ${ }^{172}$

Legally speaking, UN Security Council authorisation for a request by the AU to apply article 4(h) should in principle be given. However, China and Russia, as permanent members of the UN Security Council,

167 Principle 30.

168 See also Kuwali (n 50 above) 258-259.

169 Eg, S/RES/1593 (2005) Preamble; S/RES/2291 (2016) 10 February 2016 Preamble.

170 Kunschak (n 161 above) 67.

171 As above.

172 Kabau (n 48 above) 70. 
including their right of veto, have economic interests in Sudan's oil and have not confronted the Sudanese government. ${ }^{173}$ This casts doubts on the likelihood of the Security Council being willing or able to grant this authorisation. Nevertheless, permanent member states of the Security Council assume an increased or enhanced responsibility to protect, which entails not using their power of veto to obstruct actions that may stop mass atrocities. ${ }^{174}$ Therefore, when deciding to grant the AU's request for authorisation for an article 4(h) military intervention in Darfur, the permanent members of the Security Council should not use their veto power to block what would otherwise be a majority resolution authorising the AU to proceed.

Moreover, based on factual considerations, the situation in Darfur presented and, arguably, still constitutes a very strong case to protect people from mass atrocities by forceful military intervention under article $4(\mathrm{~h}){ }^{175}$ Thus, a denial by the UN Security Council of the AU's request for authorisation to forcefully intervene would be problematic or controversial. Furthermore, non-forceful measures in terms of Chapter VII have had a limited effect on halting the commission of international crimes against civilians. ${ }^{176}$ Indeed, although the Security Council's referral of the situation in Darfur to the ICC should be welcomed, this unintentionally or inadvertently served the interests of powerful states to, at least for the time being, avoid military intervention in Darfur. ${ }^{177}$ All these factors would strengthen the legitimacy of the $A U^{\prime}$ 's request for Security Council authorisation of military intervention.

As far as Libya is concerned, UN Security Council Resolution 1973 authorised UN member states that have notified the SecretaryGeneral, acting nationally or through regional organisations or arrangements, to use force to protect civilians in Libya and to enforce a no-fly zone over the country. ${ }^{178}$ This suggests that, if the AU had requested authorisation for an article 4(h) military intervention, the UN Security Council would have granted or would have been likely to grant it.

173 Omorogbe (n 82 above) 53; GA Critchlow 'Stopping genocide through international agreement when the Security Council fails to act' (2009) 40 Georgetown Journal of International Law 311 319-320; HIPPO Report (n 7 above) para 256; $L$ Arbour 'The responsibility to protect as a duty of care in international law and practice' (2008) 34 Review of International Studies 445 453-454.

174 A Peters 'The responsibility to protect and the permanent five: The obligation to give reasons for a veto' in Hoffmann \& Nollkaemper (n 16 above) 205-206.

175 Abass (n 16 above) 226.

176 Mills (n 74 above) 200.

177 Mills 202.

178 S/RES/1973 (2011) paras 4 \& 8. 
What ultimately prompted military intervention by NATO, under Security Council authorisation, was the imminent attack against Benghazi. Gaddafi announced that no mercy would be shown to the opposition forces in Benghazi. ${ }^{179}$ Had such an attack taken place, it was likely to have resulted in a large-scale massacre of genocidal proportions. ${ }^{180}$ Under these extreme and pressing circumstances, had the $\mathrm{AU}$ requested $\mathrm{UN}$ Security Council authorisation to militarily intervene under article 4(h), the Council was likely to have granted it.

The UN Security Council's reaction reveals that it proceeded more determinedly and quicker than the AU. However, AU military intervention under article 4(h) and the Security Council's Chapter VII powers must be regarded as complementary. ${ }^{181}$ The $\mathrm{AU}^{\prime} \mathrm{s}$ decision to apply article 4(h) should be authorised by the Security Council. As mentioned above, the UN Security Council has considered and continues to consider the situation in Libya as a threat to both international peace and security and regional stability. ${ }^{182}$ This prompted the Security Council to adopt Chapter VII measures, which is a strong indication of the likelihood that the Security Council would grant authorisation in the event of the $\mathrm{AU}$ deciding to intervene militarily. Furthermore, the Libyan case illustrates conflicting positions. Whereas the AU followed diplomatic and political solutions, the UN Security Council decided to authorise the military intervention ${ }^{183}$ implemented by NATO. As the Security Council adopted a forceful intervention approach as opposed to non-forceful methods in order to solve the Libyan crisis, a hypothetical decision by the AU to intervene militarily in Libya would have been authorised and may yet be authorised by the UN Security Council. In the latter situation, this would be the case, especially if the conflict escalated in intensity, leading to further mass atrocities.

The likelihood of the Security Council's eventual authorisation in favour of military intervention under article 4(h) in Libya may also be evidenced by the fact that three AU members and non-permanent Security Council members voted for Resolution 1973. ${ }^{184}$ Since there are three $\mathrm{AU}$ member states in the Security Council at any given time, the likelihood of being granted authorisation may increase.

179 D Kirkpatrick \& K Fahim 'Qaddafi warns of assault on Benghazi as UN vote nears' The New York Times 17 March 2011 http://www.nytimes.com/2011/03/18/world/ africa/18libya.html?pagewanted=all\&_r=0 (accessed 30 June 2016).

180 See D Bosco 'Was there going to be a Benghazi massacre?' Foreign Policy 7 April 2011, http://foreignpolicy.com/2011/04/07/was-there-going-to-be-a-benghazimassacre/ (accessed 1 july 2016).

181 Kunschak (n 161 above) 66.

182 Eg, S/RES/1973 (2011) Preamble; S/RES/2291 (2016), 13 June 2016 Preamble.

183 Kuwali \& Viljoen (n 18 above) 345.

184 UN Doc SC/10200, 17 March 2011. 


\section{Conclusion}

The situations in Darfur (Sudan) and Libya present several similarities for article 4(h) to be applied. Some important differences or particularities may, however, be identified. Whereas in Darfur, state actors are mainly responsible for mass atrocities consisting of war crimes, genocide and crimes against humanity, in Libya, actors behind mass atrocities have been more diverse and no genocide has apparently occurred. Sudan mainly has been unwilling to halt and prevent mass atrocities, as illustrated by the obstruction of ICC activities and the lack of local justice initiatives. In turn, Libya has transitioned from initial unwillingness to, mainly, an inability to stop or prevent mass atrocities. Finally, unlike Darfur, a military intervention by NATO, authorised by the UN Security Council, took place in Libya.

A sequential and cumulative test to legitimately and legally trigger the application of article 4(h) of the Constitutive Act may be identified based on article 4(h) and the Pretoria Principles. As demonstrated, the five sequential and cumulative prongs identified in this test have been met and, arguably, continue to be met with regard to Darfur and Libya. These two scenarios were, and still are, to a greater or lesser extent, characterised by protracted mass atrocities with the active involvement of, among others, (senior) state actors, amid a climate of long-term impunity and/or state inability to stop these abuses. A number of non-forceful measures or mechanisms have proven to be insufficient to prevent (further) mass atrocities. Therefore, the AU Assembly should apply article 4(h) and, in this way, authorise forceful (military) intervention in the target state subject to final authorisation by the UN Security Council. The Security Council should answer in the affirmative, taking into account the above-mentioned circumstances. Considering these circumstances in Darfur and Libya, this test has been met.

However, even if the Security Councl authorises military intervention, attention must be drawn to the manner of implementing it. The idea is that the ultimate goal of protecting civilian populations in Darfur and Libya from (further) mass atrocities may be achieved promptly and with any side or collateral effects minimised as much as possible. This is crucial to guarantee a lasting and stable situation in the target state, namely, Sudan or Libya, so that the purpose underlying an article 4(h) forceful intervention is not paradoxically defeated by side-effects stemming from such intervention. In any event, fears of potential side-effects or political reluctance regarding foreign military intervention should not become insurmountable obstacles to proceeding with forceful intervention in terms of article $4(h)$ when the protection of civilians against mass atrocities is at stake. This is precisely the situation in Darfur and Libya.

Necessary and lawful article 4(h) forceful interventions should also enhance the legitimacy of the $A U$ as an institution which, in the case 
of the target state's inability or unwillingness to protect its civilian population from mass atrocities, should effectively and efficiently intervene. For the successful application and implementation of article 4(h), well-co-ordinated action by AU organs, particularly the AU Assembly, the PSC, the African Commission and African Standby Force, is required, supported and/or endorsed by the UN Security Council, the UN and the international community as a whole. In this way, the AU can truly become the guardian of peace and security on the continent, especially when the very existence and fundamental rights of large numbers of people are severely affected by the prolonged and unpunished commission of mass atrocities. 